\title{
CLUSTER - WAY FOR INCREASING THE COMPETITIVENESS OF REGIONS
}

\author{
D. Doncheva* \\ Department of Economics, Faculty of Economics, Trakia University, Stara Zagora, Bulgaria
}

\begin{abstract}
This article provides an overview of theory concerning the cluster as a method for increasing competitiveness. In the new programming period, the EU set a new higher requirements about the measures for cluster's funds distribution. In this aspect clusters represent a new way of thinking about the regional economy, and require new roles for companies, aimed increasing their competitiveness. If the nature resources of region not properly and optimally used, i.e. turning them into competitive advantages, then the region will lose its competitive position, and as a result will worsen the economic and social situation as well as on the region and the country generally. One of the ways for increasing competitiveness of regions is the cluster approach. The formation of clusters within a region is a powerful tool for increasing the productivity of firms, employment in the region, living standards in general, and also improving the infrastructure and links to state institutions.
\end{abstract}

Key words: cluster, competitiveness, region, development

\section{INTRODUCTION}

Sustainability of the regions in the era of economic globalization, inevitably passes through competitiveness issue.

Regional competitiveness literature in academic and popular press, includes three thematic areas:

(1) definitions and conceptualizations ways for competitiveness measuring;

(2) benefits and shortcomings of strategies for increasing competitiveness;

(3) assessment of competitiveness indexes.

If the strategy applied to regional competitiveness is not effective and if factors of competitiveness are used not optimally, then the regions will lose its competitive position, which will lead to a negative impact on national competitiveness (1). Many authors, including Krugman (2, 3), assumed that competitiveness refers to achieve higher productivity, measuring the value of goods and services per unit factor production of a single territory, which will affect growth and standards of living. Martin (4) defines competitiveness as "... the ability to produce

\footnotetext{
*Correspondence to: Dora Doncheva, Department of Economics, Faculty of Economics, Trakia University, Stara Zagora, Bulgaria, Student town, 6000,e-mail: dora.doncheva@uni-sz.bg, phone number: 042699434
}

goods and services that meet the test of international markets while at the same time maintain high and sustainable levels of income or, more generally, the ability of regions to generate, while being exposed to external competition, relatively high income and employment levels ".

Regional competitiveness is inextricably related to their economic performance and can be measured by it and by assets of the regional business environment (5). The assets include: infrastructure; security; region's technical characteristics; number of firms, operating within the region; quality of labor and its availability; quality of public administration; region's historical framework; regional GDP per capita; unemployment level; average wage; FDI; innovation (6) and they influence on propensity to achieve competitive advantage in leading and growing sectors. The impact of these factors could have an impact on company competitiveness and the ability of regions to attract creative and innovative people and to ensure a high quality cultural facilities, all of which are important features of regional competitive advantages (7) .

In his writings, Porter notes that competitive advantage is created and maintained by highly localized processes and in an open economy, the success of the sub-area depends on the 
existing basic industrial structure and its sensitivity to increased international competition. Achieving sustainable competitive advantages in strong competitive pressure conditions on domestic and international markets is a key factor in achieving competitive success.

As a result of a continuous changing nature of competitive struggle is searching for new and better management approaches to enhance competitiveness and regional development. A regional development traditional approach, including mainly various forms of business subsidies, infrastructure and location of activities in the public sector, are no longer as effective with respect to maintaining and improving the companies, sectors and regions' level of success and raising the living standard. Competitiveness of companies and sectors within the region depends not only on the mechanical amount of individual companies' competitiveness, based on acquired or created competitive advantages. Company's competitiveness is largely depends on the ability of firms to cooperate with potential partners from related industries, the complexity of business services (consulting, research and development, financial services, etc.), the efficiency of public administration and political decisions that help creating a favorable business environment for economic development.

Strategic management of regions for regional development is about not just to create opportunities for developing of individual economic unit's competitiveness, and also to the development of regional competitiveness, which is associated with many complex factors, such as attracting investors, providing opportunities for business development, improved infrastructure, improved the region's population welfare and so on.

One of the ways for achieving and increasing the competitiveness of regions, hence achieving economic and social prosperity of countries is the establishment, maintenance and enlargement of clusters.

A cluster approach in the industry must create networks of related companies, research organizations and regional business structures, adequate with rapidly changing economic environment, which has the aim to positioning them in the international market.

The idea of clusters occurs even in medieval Europe, where traders and craftsmen have come together in guilds, concentrated around major cities. Since the mid 90-ies of XX century clusters, as subject of an economic agglomeration from interrelated subjects of a single territory began to be seen as an important factor for its economic development. The main conclusion of large part of the researchers of this economic phenomenon is that the regions where clusters are built become economic leaders.

Porter (8) defines clusters as "geographically connected concentration of similar, interconnected or complementary companies with active channels for business relationships, communication and dialogue, which share a specialized infrastructure, labor markets and services and face common opportunities for development and threats". In general economic scene, the cluster is" a group of geographically localized interconnected companies, equipment suppliers, complex specialized services, infrastructure, research centers and other organizations that complement each other in achieving specific economic effect and increase the competitive advantages of individual companies and cluster, generally" (9). They usually exist within a geographic region where the interaction, communication and logistics are easier and possible.

The main idea of Porter's cluster concept is that the competitiveness of the nation or region depends on the competitiveness of industries and companies involved in clusters. According to Porter, clusters also build an important institutional relations in terms of technology, skills, information, marketing and consumers'needs. These advantages enable the cluster's participants to become more productive and innovative, because of increasing their competitiveness. Competitiveness of clusters is derived from a concentration of interrelated industries, companies suppliers, access to economic infrastructure, efforts of competition and cooperation between businesses and other institutions.

Clusters promote both competition and cooperation. Competitors compete intensively to gain and retain customers. If does not have a strong competition, the cluster will fail. And still there are a cooperation, a large part of it vertically, including firms in related industries and local institutions. Competition could coexist with cooperation, because of that they occur on different dimensions and between different players (10). As Velev (11) stated "industrial clusters consist of geographically concentrated competitive enterprises in a given industry, their suppliers, companies from 
supporting industries, as well as various related organizations, who either compete, and cooperate. "

The emergence of clusters is dictated by a number of prerequisites, the most important are:

- competitive pressure - competitive advantages are crucial to the success of any organization, especially in a free market economy;

- joint projects, aimed high efficiency with minimum investment;

- cooperative use of the technical infrastructure, which is based on economies of scale and scope;

- common marketing strategies.

The basis of cluster approach is an understanding of that clusters are a combination of geographically localized chains of independent organizations that have each other vertically (through a supply chain) and horizontal (in the line of competing, coordination and cooperation) connections, which bring competitiveness and growth. They provide a synergistic effect, i.e achieve better results than the sum of companies' all component results. The enterprises that participate in clusters, achieve higher competitiveness than if they operate alone (12).

Clusters affect competition and ensure economic growth and development, mainly in three ways:

- First, through increasing a productivity of companies which are located in the area that is a result of access to specialized raw materials and supplies, specialized workforce, greater access to information to different institutions and public services and by strengthening the competition between them;

- second, through enhancing the transfer of innovation and technological knowledge between companies that are at the heart of future productivity growth;

- third, through stimulating a creation of new businesses, which will extend and strengthen the cluster itself, i.e encourage an entrepreneurship.

A cluster allows each member to gain such benefits as would have won if it were a larger scale or if it was in alliance with others, without sacrificing its flexibility.

There are different types of clusters, some of them are as follows:

- Regional clusters - companies' formation which operate in various related industries on the basis of territorial proximity that develop a culture of collaboration, combined with great innovation's opportunities and adaptation;

- Vertical clusters - companies' formation, which are linked hierarchically at different stages of production or innovation process. Here are performed joint activities with research centers and possibly resource integration, in order to be reached the necessary expertise and institutional capacity to manage large innovative projects;

- Horizontal clusters - when several branches / sectors could participate on equal terms in larger clusters;

- Sectoral clusters - cluster includes companies that operate in the same sector;

- Cross-border clusters - companies' formation, used as a tool for development of border regions, enhance local business, an investment, reduce an unemployment;

- Consortium - alliances between private limited companies formed with a strategic goal;

- Industrial areas - these include business networks, developing "hard" business links in a value chain that led to greater internationalization for both the entire network of enterprises and the region, generally.

Velev (13) defines various types of clusters based on multiple criteria:

- number of companies and industries that formed the cluster;

- type and level of integration;

- depth, width and length;

- geographical scope and configuration;

- base for creation and stage of existence;

- administration of common actions;

- product specialization;

- technological specialization;

- other.

The studies have shown that clusters typically are formed in an area (14) influenced by factors of Porter's diamond model:

- around companies, producing similar products;

- due to presence of skilled labor;

- based on key technology;

- based on presence of certain natural resources;

- based on similar customers and markets.

Regardless of the reason due to a cluster occurred, it should include approximately these companies:

- producers of finished products (they are usually a base of clusters);

- specialized suppliers;

- manufacturers of supporting products;

- infrastructure administrators:

- bodies of state and local government; 
- personnel training institutions, research units, universities, technology centers, government agencies (15).

Clusters differ from traditional forms of cooperation and integration through the next features:

- principle they are networks link several sectors and include a variety of companies that are specialized at certain units in the added value chain;

- have at least one clear leader, that could be a product, a service or a company (a branch) which determines the long-term economic, market and innovation policy of the entire cluster system;

- major economic entities are located within the area;

- participants in the cluster are interrelated and work together and the same time they compete each other;

- links between cluster's participants are sustainable;

- cluster's participants actions are long-term coordinated in terms of production and innovation programs, processes, management systems and controls;

- cluster is an innovative and strategically oriented;

- cluster membership is free and open;

- clusters are created and operate on the basis of trust between members and interaction of common interests;

- actions of the cluster are determined by collective vision for companies' and region's development and sustainability;

The benefits of being a cluster's member are:

- Enhance productivity - companies work more productively in an acquisition of resources; access to information, technology and necessary institutions; coordination with related companies; and improvements in measurement and motivation. Geographically unbounded access to resources and processes, reduces firms' production costs, which reflects in decreasing the selling price of goods and services and hence increasing sales, profits, market share and profitability of the companies respectively their competitiveness;

- Better access to employees and suppliers companies could choose from specialized human resources in the area, thereby reducing costs for search and selection. Since the cluster reduces the risk of relocation of employees, it contributes to more easily attract talented people from other places, which is a decisive advantage in some sectors. Also well developed cluster provides access to comprehensive and specialized supplier which are based locally, which also reduces companies' costs. Proximity could either improves communication and makes easier conditions for suppliers to provide support services such as installation and debugging;

- Access to specialized information - cluster builds a broad base of market information technology, competition, which is available to its members;

- Complementarity - multiplicity of links between cluster members could lead an individual unit and others to success because of their interdependence. Complementarity manifests itself in many forms. The first of them that is the most obvious is when the companies'products complement each other in meeting customers' needs. The second form is the coordination of activities across all businesses, which has aim to optimize their collective performance. The third form occurs in marketing area. Cluster often enhances the company's reputation in a particular area, which increases the likelihood buyers to seek sellers based within the region. Despite the reputation, cluster members often benefit from various joint marketing mechanisms such as trade fairs, trade magazines and marketing delegations;

- Access to public goods and institutions government and other public institutions invest in infrastructure, education and other programs that help improving company's productivity, reducing training costs, delivery costs and other;

- Better motivation and evaluation - local rivalry is highly motivating. This intensifies the competitive pressure within the cluster. Each member of the cluster is willing to and has propensity to perform better than the others. It is easier to make comparisons between the rivals in cluster, since they share common resources and has the information about the price that others paid for them. This allows a better performance evaluation relaive competitors and thus also allows to make better and accurate actions for improvements that will lead to company's superior performance compared to others;

- Better access to innovation - clusters play a key role in continued company's ability to innovate. That ability is reflected in improved productivity, which leads to growth. Cluster members usually have a broader look at the latest innovations and technological processes on the market than isolated competitors. Thus the cluster makes innovation visible to members and they could obtain them more quickly and cheaper and could use them in their activity, which enables companies to be more flexible and adaptable in terms of requirements and needs of clients and the market, generally; 
- Easier creation of new business - it is known that new companies appear in an existing market, not isolated place. Clusters provide new opportunities because the cluster members could identify gaps in products and services easily and they could build new business. Furthermore, members share common assets, resources, skills, labor and other, barriers to entry are lower than elsewhere. Another advantage of the cluster is that local financial institutions and investors have already familiar with their business and because of that they may require a lower risk premium on equity. Also new companies could take advantage of relationships and market that have already established. Creation of new enterprises expand the cluster, which is a positive region's feature, which is a sign of company's progress within the region, compared with its competitors outside and that increases the competitiveness of both companies and the region.

Besides benefits, there are negatives to the cluster participants:

- as cluster members are connected and dependent on each other, if there is an unfavorable economic situations, the poor performance of one of them could may affected others, negatively;

- there is a possibility of forming a cartel, if there is an absence of effective government regulation;

- there is a possibility of conflict of interest and contradictory situations, according to the Law on Protection of Competition.

(16)The existence of clusters within a region brings a number of benefits for it:

- Regional Development;

- Symbiosis of fundamental science and practical developments leading to the emergence of newproduct types and improvments of production conditions;

- Applied innovation lead to developed production infrastructure ;

- Development of national and regional policies to support public-private partnerships;

- Raising the living standard of the region.

\section{CONCLUSION}

The focus on regions influence the growing consensus that they are primary spatial units that compete for investment and knowledge that at the regional level are distributed and transferred between agglomerations or clusters of industrial firms and firms operating in the service sectors.

The cluster approach is increasingly used in government policies. Changing environmental conditions and new challenges facing modern business are a reason for growing attention on them :

- the need for geographical concentration and concentration of supply of complex of financial, consulting, legal and other services necessary for operation of businesses;

- rapidly changing market requirements impose a more flexible and specialized response to consumer expectations;

- constant pressure on firms to provide new and improved products and services related to the opportunities of creation and access to innovation;

- clusters are carriers of advantages naturally set in them that are related to the synergy resulting from general access to resources or markets, leading to increased competitiveness of industry in a given branch (sector) and improve the living standards and welfare of the population in the region;

- the cluster approach used to impact on business indirectly is the result of conscious fact that systematic measures that are aimed at a group of companies concentrated in certain spatial borders, always carry a greater effect than measures aimed at companies considered as separate objects of state regulation.

\section{REFERENCES}

1. Vukovic D., Correlation analysis of indicators of regional competitiveness: the case of the republic of Serbia, Economic Horizons, 15(3): 201 - 215, 2013;

2. Krugman, P., Competitiveness: A Dangerous Obsession, Foreign Affairs, 73 (2) : 28-44, 1994.

3. Krugman, P., Making sense of the competitiveness debate, Oxford Review of Economic Policy, 12 (3):17-25, 1996;

4. European Commission, In: Martin RL (Ed.), A Study on the Factors of Regional Competitiveness. Draft final report for The European Commission Directorate-General Regional Policy, Bruselas: Cambridge Econometrics. Ecorys-NEI, p. 2, 2003;

5. Malecki EJ, Cities and regions competing in the global economy: Knowledge and local development policies, Environment and Planning C: Government and policy, 25 (5): 638-654, 2007. Available at: dx.doi.org/10.1068/c0645;

6. Joksimovic L., Spillover of FDI and Human Capital Development: Transition economies and Serbia. In: V. Babic, Lj. Maksimovic (Eds.), Foreign capital as a factor of development of the countries in transition, Kragujevac, Serbia: Faculty of Economics, University of Kragujevac, pp. 77-95, 2008;

7. Kitson M., Martin R., \& Tyler P., Regional competitiveness: An elusive yet key 
concept ?, Regional Studies, 38 (9): 991999, 2004;

8. Porter M., Cluster and new economics of competition, Harvard Business Review, issue from november-december 1998. Available at:

https://hbr.org/1998/11/clusters-and-thenew-economics-of-competition;

9. Clusterite - forma za povishavane na konkurentosposobnostta na biznesa, Enterprise Europe network. Available at: http://ec.europa.eu/enterprise-europenetwork;

10.Porter M., Cluster and new economics of competition, Harvard Business Review, issue from november-december 1998. Available at:

https://hbr.org/1998/11/clusters-and-thenew-economics-of-competition;
11.Velev M., Klasteren podhod za povishavane na konkurentosposobnostta. Sofia: Softreyd, 2007;

12.Velev M., Klasteren podhod za povishavane na konkurentosposobnostta. Sofia: Softreyd, 2007;

13.Velev M., Klasteren podhod za povishavane na konkurentosposobnostta. Sofia: Softreyd, 2007;

14.Velev M., Klasteren podhod za povishavane na konkurentosposobnostta. Sofia: Softreyd, 2007;

15.Velev M., Klasteren podhod za povishavane na konkurentosposobnostta. Sofia: Softreyd, 2007;

16. Klusterni praktiki v Bulgaria, Natsionalen buletin: Nauka I biznes, 2013, Available at: http://s2b.mon.bg. 